\title{
Analysis of workplace health and safety, job stress, interpersonal conflict, and turnover intention: a comparative study in the health sector
}

\begin{abstract}
BACKGROUND
This study aims to examine the relationship between workplace health, job stress, turnover intention and interpersonal conflict in the health sector. It also seeks to unravel how the public and private working environment, and demographic variables affect those four variables.
\end{abstract}

\section{PARTICIPANTS AND PROCEDURE}

A cross-sectional survey design was used for this study. The respondents were selected based on simple random sampling. Out of 1000 questionnaires administered, 708 were returned (432 from public hospitals and 276 from private hospitals) and used. Correlation, multiple regression, and ANOVA analysis were used to determine the relationship and impact between the variables.

RESULTS

The findings revealed negative and significant relationships between workplace health and safety and stress, turnover intention and interpersonal conflict. Additionally, some results reflected the significant positive relationship between stress, turnover intention and interpersonal conflict. Finally, turnover intention, job stress, education level and number of duties accounted for $30 \%$ of the variation in workplace health and safety.

\section{CONCLUSIONS}

Managers within the healthcare sector of Turkey should acknowledge that workers who do not feel healthy and safe in work environments develop high stress, turnover intention, and conflict with other colleagues.

\section{KEY WORDS}

workplace safety in Turkey; workplace health in Turkey; job stress; interpersonal conflict; turnover intention

ORGANIZATION - Bower Hospital, Diyarbakir, Turkey

AUthors' Contributions - A: Study design - B: Data collection - C: Statistical analysis - D: Data interpretation .

E: Manuscript preparation · F: Literature search · G: Funds collection

CORRESPONDIng AUthor - Cengiz Mengenci, Ph.D., Bower Hospital, Elazığ Cd. 2/9, Yenişehir-Diyarbakır,

21100 Diyarbakır, Turkey, e-mail: cengizmengenci@yahoo.com

to Cite this ARtıcle - Palancı, Y., Mengenci, C., Bayraktaroğlu, S., \& Emhan, A. (2021). Analysis of workplace health

and safety, job stress, interpersonal conflict, and turnover intention: a comparative study in the health sector.

Health Psychology Report, 9(1), 76-86. https://doi.org/10.5114/hpr.2020.99971

RECEIVED 01.06.2020 • REVIEWED 14.08.2020 • ACCEPTED 26.08.2020 • PUBLISHED 15.10.2020 


\section{BACKGROUND}

The International Labor Organization (ILO) report shows that not only developed but also developing countries face serious issues such as work-related deaths and injuries (Hwang et al., 2014). The latest predictions made by the ILO are that every year 2.78 million workers die because of occupational accidents and work-related diseases; an additional 374 million workers experience non-fatal occupational accidents. Globally, workdays lost are estimated to represent $4 \%$ of the world's gross domestic product (GDP), and may rise to $6 \%$ or more in some countries (Hauge et al., 2007). All fatalities, injuries, and disease result in a great amount of resources lost. Due to such great losses, workplace health and safety have attracted the increasing attention of researchers, organizational managers, and also policymakers (Amponsah-Tawiah \& Mensah, 2016). One off the areas researchers have focused on is that of health in institutions that could be deemed demanding, stressful, tiring and accordingly dangerous workplaces. Burdensome tasks, heavy workloads, handling infectious agents such as exposure to blood, body fluids and other contaminants, acute respiratory disease, outbreak response in community settings, as well as insufficient time, shortage of professionals, never-ending working hours, uncertain shift work, conflict with other colleagues, high job expectation, irresponsibility of patients, uncertainty concerning treatment of patients, epidemic diseases of patients facing death, and dying people make such jobs hardly tenable (Bennet \& Robinson, 2000). Moreover, there has been extensive violence against healthcare staff in health-care institutions. Both patients and patient's relatives confront healthcare staff with not only physical but also verbal violence (Annagür, 2010). For all these reasons, health institutions are prone to accidents and injuries; and the workplace health and safety issue looms as more important in health institutions.

Unfortunately, despite the importance of workplace health and safety, only a limited amount of empirical research has been conducted in the Turkish health sector. Researchers have focused on the occurrence of psychological violence behaviors (Coşkun \& Karahan, 2019); occupational risk (Meydanlıŏlu, 2013); implementing services for preventing accidents and disease in health institution (Özkan \& Merioğlu, 2006); occupational accidents (Özay \& Coşkun, 2017); management and training systems such as policies, procedures and difficulties (Hizıroğlu et al., 2012); occupational health system and current education, legislation and practice (Örnek \& Esin, 2015); occupational safety scale (Öztürk et al., 2012); and work environment, working conditions and outcome of occupational accidents (Ergör et al., 2003). Additionally, some other researchers fo- cus on the health and safety perception of workers in construction sites (Ulubeyli et al., 2014). However, within the Turkish health sector, no study has been conducted to investigate the relationship of workplace health and safety with interpersonal conflict, job stress, and turnover intention. Furthermore, it is not known how much demographic variables affect variables and their relationships. For this reason, the objective of the present study was to investigate the relationships of workplace health and safety, interpersonal conflict, job stress, turnover intention and the role of demographic variables - how they affect these variables' relationships. Moreover, the present study has the objective of understanding how public and private health institutions differ in the issue of workplace health and safety.

\section{LITERATURE REVIEW}

Workplace health and safety is defined as supporting the safety, health and welfare of people engaged in work and employment (Bhagawati, 2015); workplace health and safety encompasses the mental, emotional, and physical well-being of the worker during working hours, and the achievement of organizational goals. Therefore, improving the workplace safety and health management system should be accepted as arousing awareness, and exhibiting understanding of motivation and commitment for all those who work within an organization. However, ultimately any success will rely on the management's commitment (Civil Aviation Safety Authority, 2002; Haq, 2011).

Workplace safety and health is also accepted as a function of management in any organization devoted to improving its quality and efficiency (Bayraktaroğlu et al., 2018). Management dedication has an important role in all aspects of safety intervention (Gyekye, 2005). Dedication involves awareness and supportive safety in top level attitudes towards employees' safety (Yavuz \& Akça, 2018). It was posited that top level management dedication to positive and supportive safety attitudes towards their employees' safety has an extensive effect on employees' commitment to the organization and also accident reduction (Vredenburgh, 2001). Of note is that management safety practices and commitment to safety decrease workplace injuries (Alli, 2008). Moreover, management policies, practices, and attitudes have a direct impact on safety in Canadian manufacturing firms (Geldart et al., 2010). Researchers found that when employees feel and are convinced that their supervisor demands strict adherence to safety rules and procedures, they conform to safety procedures, willingly (Vredenburgh, 2001). To summarize, it can be said that the employees' workplace safety and health is greatly determined by the supervisors' behaviors,
Health and safety, job stress, interpersonal conflict, and turnover intention 
Yılmaz Palancı,

Cengiz Mengenci,

Serkan

Bayraktaroğlu,

Abdurrahim

Emhan attitudes and understanding towards safety issues. Moreover, the supervisors' safety practices include the extent to which a supervisor keeps track of unsafe practices, and their acknowledgement of workers who adopt safe work behaviors.

Person-environment (P-E) fit theory posits that job stress and dissatisfaction result from a misfit between the worker's values, preferences such as work health and safety understanding and his/her working environment (Edwards \& Rothbard, 1999). Porter and Steers (1973) found that when the employee enters the organization they have many expectations. If these expectations are not met, the employee will most likely be dissatisfied, stressed out, and in the end leave the organization. Unmet expectation causes stress. If stress is experienced in the workplace it is life-threatening to the individual. For this reason, managers and also workers must pay attention to the effects of stress. Stress is a hard topic to define since the level of stress and effects of it vary from one person to another; also individuals' reactions to stress differ even in the same situation. Stress symptoms can be delineated as follows: psychological symptoms that are inactive, such as unhappiness, nervousness and irritation; physical symptoms that are due to unequal incretion, such as pain, disturbance, restlessness; behavioral symptoms due to less participation, less will, absence, and turnover (Hwang et al., 2014). Moreover, under the influence of stress, employees lose their capability and skill to cope with the environment and job requirements; the aforesaid phenomenon causes fluctuation in the standard psychosomatic and physical state of employees (Khan et al., 2014). As mentioned above, stress can occur for individual reasons. On the other hand, in any organizational environment, there are some other reasons behind stress, such as the working environment, workload, career advancement, management style, working relationships, organizational support, work itself, rewards systems, job security, job autonomy, role conflict, ambiguity, and role control (Basińska \& Sołtys, 2020; Lu et al., 2012; Macdonald et al., 2000; Konstantopoulos et al., 2009; Walsh et al., 1985). High stress level might result in turnover.

Turnover is not a kind of behavior happening suddenly. It is definite response to planned action. Researchers have conducted studies to understand reasons behind this behavior. Turnover is defined as the ratio of the total number of workers who have left an organization during the period of time considered divided by the average number of workers in the organization during the same period (Price, 1977). Turnover factors can be categorized under job and organizational related reasons. Job-related reasons are job stress, job dissatisfaction (Firth et al., 2007), powerlessness, locus of control, personal control, economic reasons (Mano-Negrin \& Tzafrir, 2004), role stressor, role ambiguity (Kahn et al., 2014), unknown expectations, performance evaluation methods and job pressures (Guimaraes, 1997). Organizational reasons are instability of organizations (Alexander et al., 1994; Zuber, 2001), work oriented management methods (Simon et al., 2007), lack of communication (Labov, 1997), lack of employee empowerment (Magner et al., 1996), poor human resource management policies, wrong management practices, lack of grievance systems, lack of motivation, and salary (Griffeth et al., 2000). When the turnover rate is increased, there are significant and detrimental consequences. Turnover significantly affects profitability (Barrows, 1990), customer service and satisfaction (Gustafson, 2002), hiring and training cost (Johnson et al., 2000), and loss of social capital (Stovel \& Bontis, 2002).

Another important issue in organizations is interpersonal conflict. Researchers studied when and how interpersonal conflicts occur in organizations (Notelaers et al., 2018). Personality differences, lack of information, role incompatibility, job and working environmental related stress are accepted as sources of conflict (Hauge et al., 2007). Moreover, some researchers have posited that organizational change, culture, loss of status, lack of trust, personality mismatch, discrimination and incivility are other reasons behind interpersonal conflict in the working place (Budd et al., 1996; Coşkun \& Karahan, 2019; Hart et al., 2004).

The literature on social exchange theory and reciprocity theory is mostly used by safety researchers to explain how supervisors' dedications to safety issues change and regulate followers' perception to accept and support safety behavior in the working environment (Neal \& Griffin, 2004). According to social exchange theory and reciprocity theory, when an individual provides a service for somebody, it is always in anticipation of a positive return (Blau, 1964; Michael et al., 2005). Extending this understanding to workplace health and safety, it would be expected that when supervisors, managers or owners of the company show their devotion to and support of health and safety in organizations, workers reciprocate by their time, energy and effort to obey and sustain safety rules, regulations and laws (Stovel \& Bontis, 2002). This positive safety psychology causes positive results for the organization such as decrease in stress level, turnover intention and interpersonal conflict (Micheal et al., 2005). This study aims to understand the relationship between the aforesaid variables, and then to evaluate the effect of demographic variables on them.

As a result of the theoretical background, the hypotheses may be listed as follows:

$\mathrm{H} 1$ : There is a positive relationship between interpersonal conflict, intent to leave, and job stress.

$\mathrm{H} 2$ : There is a negative relationship between interpersonal conflict, intent to leave, job stress and workplace health and safety. 


\section{PARTICIPANTS AND PROCEDURE}

\section{PARTICIPANTS}

To test the hypotheses and model, a 76-item questionnaire and 8 demographic variables were used. The research was conducted on two types of hospitals in Diyarbakir, the largest city in southeast Turkey. There are three governments and six private hospitals operating in the center of the city. The questionnaires were distributed stratified randomly. After eliminating 9 questionnaires, 708 questionnaires were collected from the hospital staff for further analysis.

Some of the demographic information about participants is presented in Table 1 . As shown in the table, the survey had 432 participants from government hospitals and 276 participants from private hospitals.

\section{MEASURES}

Except for the demographic variables, four different scales were used to rate employees' work health, work stress, interpersonal conflict, and intent on leaving the work levels.

Demographic data form. This questionnaire aimed at collecting the demographic information of the employees of the institution: age, gender, education status, marital status, work experience, weekly overwork, number of monthly duties, position/title and what department the employee works in.

Workplace Health Scale. In order to measure the work health levels of employees, the workplace health scale was used (Öztürk et al., 2012). The scale was composed of 45 items (e.g., "measures taken against work accidents in the workplace are sufficient") and 7 subscales: occupational disease and complaints, medical checkup and record system, accidents and intoxication, management support and approach, tools and equipment inspection, protective and prevention rules, physical compatibility environment. A 6-point Likert scale with values of 1 (strongly disagree), 2 (disagree), 3 (slightly disagree), 4 (slightly agree), 5 (agree) and 6 (strongly agree) was used as the instrument. As a result of the reliability analysis, the Cronbach's $\alpha$ score was determined to be .80 . Kurtosis and skewness scores are between -1 and 1 and the distribution is normal.

Occupational Stress Scale. The occupational job stress scale was used (Baltaş et al., 1998; Cohen \& Williamson, 1988) using 14 questions (e.g., "Do you feel like you have a heavy workload that cannot be finished?") on a 5-point Likert scale: 1 (never/ almost never), 2 (rarely), 3 (sometimes), 4 (often) and 5 (always). As a result of the reliability analysis, the Cronbach' $\alpha$ score was determined to be .86. Kurtosis and skewness scores are between -1 and 1 and the distribution is normal.
Table 1

Demographic variables $(N=708)$

\begin{tabular}{|c|c|c|c|}
\hline Variables & $\begin{array}{l}\text { Government } \\
\text { hospitals } \\
\text { Frequency }(\%) \\
n=432(61)\end{array}$ & $\begin{array}{c}\text { Private } \\
\text { hospitals } \\
\text { Frequency (\%) } \\
n=276(39)\end{array}$ & \multirow{6}{*}{$\begin{array}{l}\text { Health } \\
\text { and safety, } \\
\text { job stress, } \\
\text { interpersonal } \\
\text { conflict, } \\
\text { and turnover } \\
\text { intention }\end{array}$} \\
\hline \multicolumn{4}{|l|}{ Gender } \\
\hline Male & $205(47.5)$ & $126(45.7)$ & \\
\hline $\begin{array}{c}\text { Female } \\
\text { Age (years) }\end{array}$ & $227(52.5)$ & $150(54.3)$ & \\
\hline $20-30$ & $228(52.8)$ & $155(56.2)$ & \\
\hline $31-40$ & $151(35.0)$ & 89 (32.2) & \\
\hline 41 and over & $53(12.2)$ & $32(11.5)$ & \\
\hline \multicolumn{4}{|l|}{ Marital status } \\
\hline Married & $243(56.3)$ & $148(53.6)$ & \\
\hline Single & $189(43.7)$ & $128(46.4)$ & \\
\hline \multicolumn{4}{|l|}{ Education } \\
\hline High school & $130(30.1)$ & $84(30.4)$ & \\
\hline University & $229(53.0)$ & $144(52.2)$ & \\
\hline $\begin{array}{l}\text { Graduate } \\
\text { education }\end{array}$ & $73(16.9)$ & $48(17.4)$ & \\
\hline \multicolumn{4}{|l|}{ Job position } \\
\hline $\begin{array}{l}\text { Health } \\
\text { technician }\end{array}$ & $101(23.4)$ & $65(23.6)$ & \\
\hline Nurse & $218(50.5)$ & $137(49.6)$ & \\
\hline $\begin{array}{l}\text { Physician } \\
\text { (doctor) }\end{array}$ & $113(26.2)$ & $74(26.8)$ & \\
\hline \multicolumn{4}{|l|}{ Tenure } \\
\hline $1-5$ & $193(44.7)$ & $138(50.0)$ & \\
\hline $6-10$ & $111(25.7)$ & $60(21.7)$ & \\
\hline $11-15$ & $67(15.5)$ & $38(13.8)$ & \\
\hline $16-20$ & $30(6.9)$ & $15(5.4)$ & \\
\hline $21+$ & $31(7.2)$ & $25(9.1)$ & \\
\hline \multicolumn{4}{|l|}{ Working place } \\
\hline Services & $193(44.7)$ & $121(43.8)$ & \\
\hline Emergency & $91(21.1)$ & $49(17.8)$ & \\
\hline $\begin{array}{l}\text { Diagnosis- } \\
\text { examination }\end{array}$ & $44(10.2)$ & $25(9.1)$ & \\
\hline Other & $104(24.1)$ & $81(29.3)$ & \\
\hline \multicolumn{4}{|c|}{ Number of monthly watching } \\
\hline $\begin{array}{l}\text { Not keeping } \\
\text { watch }\end{array}$ & $296(68.5)$ & $135(48.9)$ & \\
\hline Keeping watch & $136(31.5)$ & $141(51.1)$ & \\
\hline
\end{tabular}


Yılmaz Palancı,

Cengiz Mengenci,

Serkan

Bayraktaroğlu, Abdurrahim Emhan
Interpersonal Conflict Scale. In order to measure the interpersonal conflict levels of employees, the interpersonal conflict scale was used (Mulki et al., 2015). A 5-point Likert scale - 1 (strongly disagree), 2 (disagree), 3 (neither agree nor disagree), 4 (agree) and 5 (strongly agree) - was used as the instrument for a 4-item interpersonal conflict scale (e.g., "I can argue with other employees at work"). As a result of the reliability analysis, the Cronbach's $\alpha$ score was determined to be .82 . Kurtosis and skewness scores are between -1 and 1 and the distribution is normal.

Turnover Intention Scale. In order to measure the turnover intention levels of employees, the turnover intention scale was used (Walsh et al., 1985). A 5-point Likert scale with values of 1 (never/almost never), 2 (rarely), 3 (sometimes), 4 (often) and 5 (always/almost always) was used as the instrument for an 8-item turnover intention scale (e.g., "I will leave this hospital as soon as I find a better job"). As a result of the reliability analysis, the Cronbach's $\alpha$ score was determined to be .92 . Kurtosis and skewness scores are between -1 and 1 and the distribution is normal.

\section{STATISTICAL DATA ANALYSIS}

To evaluate the collected data, SPSS 22 software was used. To compare the study variables, parametric difference tests ( $t$-test, ANOVA), multiple regression and correlation analysis were used. The data were analyzed according to the summative scales of the participants. The level for statistical significance is accepted as $p<.05$.

\section{RESULTS}

Private hospital workers' work health level is higher than private hospital workers $(t=3.94, p<.001)$. Male workers' interpersonal conflict, job stress and turnover intention level are higher than private health sector workers $(t=3.79, p<.001, t=3.04, p<.01$, $t=2.13, p<.05)$. Among male workers who are on duty regularly, job stress, interpersonal conflict and turnover intention levels are higher than those of off-duty workers $(t=5.14, p<.001, t=6.42, p<.01$, $t=3.40, p<.01)$.

Services, emergency units and intensive care unit workers' job stress and turnover intention levels are higher than in diagnosis units $(F=9.79, p<.001$, $F=5.09, p<.01)$. In workers aged between 31 and 40 job stress levels are higher than in those aged 41 or over $(F=4.84, p<.01)$. Employees with more than 21 years of experience have higher levels of interpersonal conflict and less job stress than other groups $(F=3.72, p<.01, F=3.24, p<.05)$. High school graduated workers' job stress levels and interpersonal conflict levels are lower than in university graduate workers $(F=9.33, p<.001, F=14.44, p<.001)$. Doctors' job stress level is higher than in nurses and other technicians $(F=7.40, p<.01)$. Doctors' workplace health level and safety level is lower than in nurses and other technicians $(F=11.00, p<.001)$. In workers working more than 16 extra hours in a week, job stress level, interpersonal conflict level and turnover intention level are higher than in the other groups of workers $(F=7.82, p<.001, F=12.50, p<.001, F=9.42$, $p<.01$ ). Also in workers working more than 16 hours extra hours in a week, work health level is lower than in workers working 1-5 extra hours in a week $(F=10.32, p<.01)$. Male workers' interpersonal conflict and job stress levels are higher than in female workers $(t=3.82, p<.001, t=3.04, p<.01, t=2.13$, $p<.05)$.

In Table 2, the results indicate moderate negative relationships between workplace health and safety and interpersonal conflict $(r=-.20, p<.001)$ and turnover intention $(r=-.23, p<.01)$ and job stress $(r=-.28, p<.01)$. Both of the hypotheses of this study are supported. On the other hand, there are positive and moderate relationships between interpersonal conflict and turnover intention $(r=.54, p<.001)$; and job stress $(r=.53, p<.01)$; and also there is a positive and moderate relationship between turnover intention and job stress $(r=.59, p<.01)$.

According to correlation results, both hypotheses were supported.

Table 3 indicates that all five variables' relationships were statistically significant. For assessing the contribution of variables, the standard multiple regressions analysis was conducted. The $R^{2}$ value indicated that turnover intention, job stress, education level, and number of duties accounted for $30 \%$ of the variation in workplace health and safety.

\section{DISCUSSION}

This study explored the relationship between job stress, interpersonal conflict, turnover intention, workplace health and safety and also how these variables differ according to the demographic variables. For these purposes, two hypotheses were conceived and supported with the results. These results are congruent with the literature as well. The correlation analysis of the study confirmed that there is a positive and moderate relationship between job stress, interpersonal conflict and turnover intention. This result means that the higher the stress, the higher are the potential levels of conflict and turnover in a company. Also there is a negative and moderate relationship between job stress, interpersonal conflict, turnover intention and workplace health and safety. This result means that if workplace health and safety level decreases, job stress increases, so that interper- 


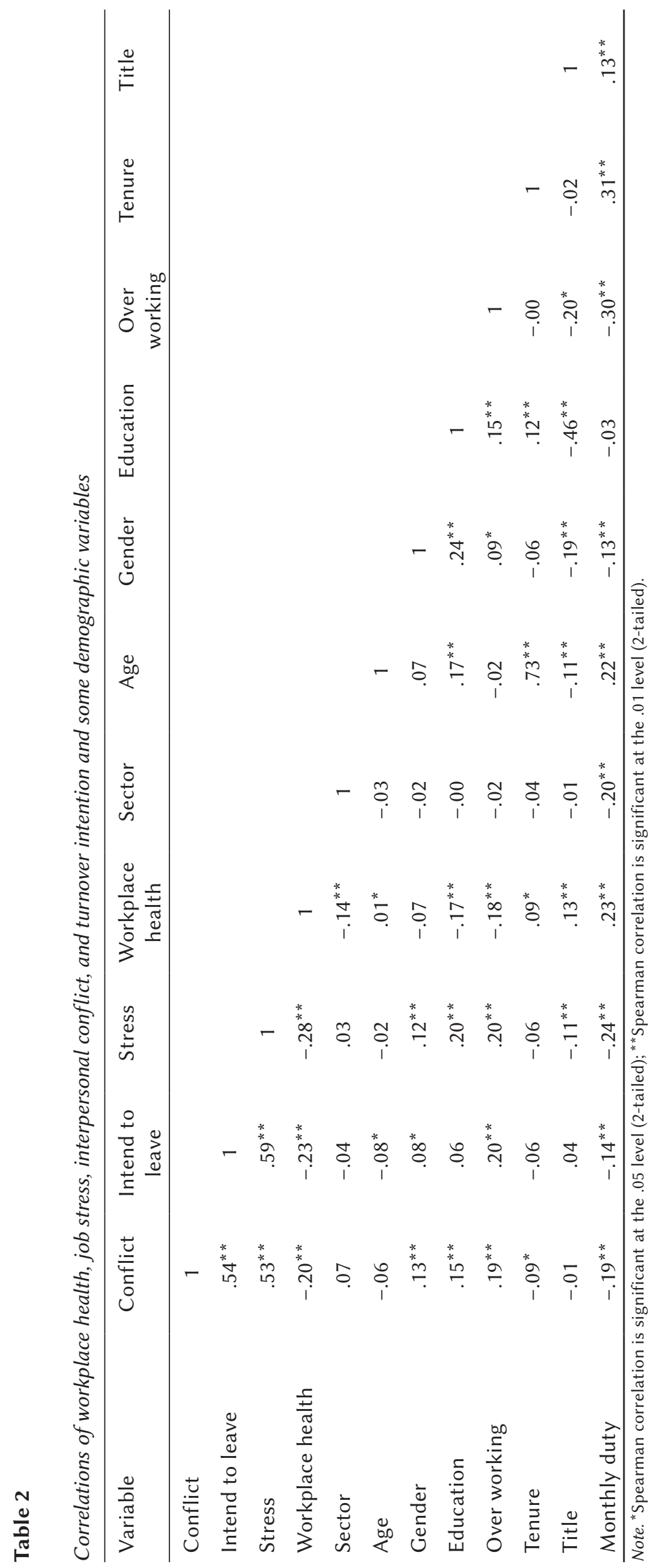

Health and safety, job stress, interpersonal conflict, and turnover intention 
Table 3

Effect of intent to leave, job stress, education level, number of duties on workplace health

\begin{tabular}{|c|c|c|c|c|c|c|c|c|}
\hline $\begin{array}{l}\text { Dependent } \\
\text { variable }\end{array}$ & $R^{2}$ & $\begin{array}{c}\text { Adjusted } \\
R^{2} \\
\end{array}$ & $\begin{array}{c}\text { Independent } \\
\text { variable }\end{array}$ & B & $\beta$ & $t$ & $p$ & VIF \\
\hline \multirow{11}{*}{$\begin{array}{l}\text { Workplace } \\
\text { health } \\
\text { and safety }\end{array}$} & \multirow[t]{11}{*}{.30} & \multirow[t]{11}{*}{.27} & Interpersonal conflict & 0.22 & .02 & 0.28 & .783 & 1.62 \\
\hline & & & Intent to leave & -0.89 & -.18 & -2.43 & .019 & 2.10 \\
\hline & & & Job stress & -1.12 & -.27 & -3.81 & $<.001$ & 1.80 \\
\hline & & & Sector & -3.32 & -.41 & -0.81 & .424 & 1.13 \\
\hline & & & Age & -2.34 & -.35 & -0.46 & .652 & 2.24 \\
\hline & & & Gender & 1.29 & -.16 & -0.27 & .786 & 1.20 \\
\hline & & & Education level & -14.68 & -.25 & -3.54 & .001 & 1.61 \\
\hline & & & Over working & -1.24 & -.04 & -0.68 & .492 & 1.22 \\
\hline & & & Tenure & 5.13 & .13 & 1.69 & .073 & 2.24 \\
\hline & & & Job position & 0.34 & .06 & 0.08 & .941 & 1.33 \\
\hline & & & Number of duties & -1.74 & -.12 & -2.62 & .029 & 1.01 \\
\hline
\end{tabular}

\footnotetext{
Yılmaz Palancı,

Cengiz Mengenci, Serkan

Bayraktaroğlu, Abdurrahim Emhan
}

sonal conflict and turnover intention increase. Also, the regression analysis results showed that there are positive and weak relationships between work health and safety and interpersonal conflict, negative and moderate relationships between job stress, turnover intention, education level, number of duties and work health and safety. Turnover intention, job stress, education level, number of duties and interpersonal conflict explain 30\% of variance change of the work health and safety.

These results are consistent with earlier studies (Çetinkaya \& Aras, 2017; Frone, 2000; ILO, 2019; Leblebici, 2012; Liu et al., 2019; Yavuz \& Akça, 2018). Some of the researchers consider that there is a strong and positive relationship between interpersonal conflict and intent to leave the organization (Haq, 2011). Some researchers explored the relationship between interpersonal conflict, organizational outcomes and personal outcomes (Frone, 2000). In that study, there was a negative and moderate relationship between interpersonal conflict, job satisfaction and organizational commitment and also a positive relationship with turnover intention. In another study, positive and moderate relationships were found between job stress, burnout, turnover intention and interpersonal conflict (Yavuz \& Akça, 2018). In organizations, some of the interpersonal conflicts occur due to a lack of supervisor or coworker interest in workplace health and safety. As it is mentioned in the studies that workers feel and accept the lack of interest about work and workplace health and safety issues, this conflict might cause high level job stress and drive turnover intention. Researchers categorized job stress dimensions as duty-related stress, role-related stress, working environment related stressors, and organizational policies related stressors and interpersonal relations related stressors (Michael et al., 2005). Furthermore, their study results showed a positive and moderate relationship between job centered stress and intention to leave the organization. All of the above studies' results show that when stress level increases in an organization consequences would be high-level interpersonal conflict and turnover intention and this supports the results of this study. Another study was conducted in the Ghanaian power industry (Liu et al., 2019). In their study, workplace health and safety and turnover intention were negatively related. In another study, Arshadi and Damiri (2013) conducted research to understand the relationship between job stress and turnover intention in the Iranian National Drilling Company. According to results from this study, job stress and turnover intention are positively correlated. Nevertheless, in Taiwanese banks, Chen et al. (2011) found in their study a positive relationship between the role conflicts, role ambiguity and role overload and job stress. Furthermore, employees with a high level of job stress are more prone to leave organizations. Also, among 306 telecom engineers, Shaukat et al. (2017) suggested in their study that conflict is negatively related to task performance and contextual performance and positively related to turnover intention and three dimensions of job burnout.

In this study, effects of demographic variables on workplace health and safety, job stress, intent to leave, and turnover intention were also examined. In this study public hospital workers' workplace health level was higher than that of private hospital work- 
ers. This happens because in public hospitals, managers and other health and safety officers might take strict measures and inspect the working environment against accidents and injuries. In the private sector, managers and safety officers might not give enough importance to safety issues and enforcement of all regulations and laws to reduce accidents and injuries. They might do their job as if they really care. In the private sector, one and all focus on expenses and having a regular doctor, not on having safety training, a role which is assigned to a health officer. They have responsibilities other than the actual one. Public hospitals are established in the sector earlier than private hospitals. This gives public hospitals the advantage to become more experienced and accumulate solutions to prevent accidents and injuries. Another result is that the male workers' interpersonal conflict, job stress and intent to leave levels are higher than in female workers. In masculine society, sexuality defines most of the issues - even how much responsibility is shared between sexes in all environments. Also, male workers might take all responsibilities and this might cause them to experience burnout faster than female workers. Moreover, males are more prone to lose their temper.

The number of duties demographic variable is also examined in this study. In hospitals, health workers have duty responsibility to give and sustain 24-hour health services to patients in services. Most of the workers, having a duty, work in the emergency room. In the emergency room, workers come face to face with the patients' relatives. Sometimes they are confronted with violence from the patients' relatives; they might be blamed for not providing good healthcare to patients. Long and ongoing tiring hours for the workers, work overload, and role ambiguity might increase job stress, interpersonal conflict and intent to leave.

The job stress level of workers providing medical services is examined in this study - their intent to leave, the turnover intention. Results show that the emergency room and intensive care unit's workers' job stress and intent to leave level are higher than with the workers of other units. Some medical services such as in the intensive care and emergency room are accepted as a fault-free working environment. This unit's workers face and treat a much more atrisk group of patients. This unit's patients are physically and psychologically more problematic. The emergency room and intensive care unit face a greater possibility of patient loss, and workers suffer from more frequent loss of their patients. More importantly, intensive care and emergency room patients' relatives' demands, wants, aggressive behaviors and psychological situations exceed this unit's workers' toleration level. All the above factors can increase job stress and intent to leave among the emergency room and intensive care unit workers. Study results show that at the age between 31 and 40 workers' stress level is higher than at age 41 or over.

Middle-aged group workers are more stressed out for the following reasons. Young workers have more demands and expectations from life. But when they get older, their wants, demands and expectations might gradually decrease. Then they may become more tolerant in general. Also, workers older than 41 years are assigned to less demanding units. These factors might be explained by the results.

Another important factor in working life is experience. In this study, the results show that with a 21-year-old's experience the workers' interpersonal conflict and job stress levels are lower than with the other groups. Older and experienced workers become more mature and their careers become more stable. Moreover, older workers are respected and discrimination is positive, for example they are not assigned extra work and responsibility. These factors might decrease older workers' stress and conflict level.

In a working environment, workers have different levels of education. Results attained from this study show that high school graduate workers' stress and conflict level is lower than that of university graduate workers. Workers with university or higher-level education might surmise that they are unable to get whatever they deserve. The higher the education level, the higher the expectations are. This reason might be behind the aforesaid results.

In the hospital, doctors, nurses, lab technicians, etc. work to help patients. The study results show that doctors' stress level is higher than that of nurses and technicians. Doctors face not only patients' and also relatives' extreme demands, wants, expectations and physical violence. This working environment and patients' and relatives' close relationship might increase doctors' stress levels. According to the results, doctors' work health and safety level is lower than that of nurses and technicians. Nurses and technicians' working hours are much more determined and stable than those of doctors. Especially in intensive care and emergency units, doctors might be called late at night or early in the morning when the patients' situation worsens. Also surgery doctors may have an operation after hours. Such working conditions have a negative effect on the doctor's health and safety level. Another result from this study also explains the doctors' health and safety level. The results show that with workers working more than 16 hours a week, the stress, conflict, and intent to leave levels are higher than in all other groups. Long working hours directly affect workers both physically and psychologically and also put an extra burden on workers' shoulders. This situation increases the stress level of the workers; then it sometimes causes individuals to lose their tempers, and conflict might occur.
Health and safety, job stress, interpersonal conflict, and turnover intention 


\section{CONCLUSIONS}

This study aimed at examining the relationship between workplace health, job stress, turnover intention and interpersonal conflict in the health sector. Thus, this study is an attempt to explore how public and private working environments, as well as demographic variables, affect those four variables.

This study contributed to present knowledge by making comparisons and cross-sectional analyses
Yılmaz Palancı, Cengiz Mengenci, Serkan

Bayraktaroğlu, Abdurrahim Emhan employing a complex research model. Workplace health levels at public and private health organizations have been analyzed in relation to important issues and variables affecting workplace health in today's organizations. The findings and results of this study support present theory and research indicating that the quality of working culture and environment created by organizational strategies and leadership play an important role to create healthy and safe workplaces as a means of happy and productive systems. This study also adds to the few studies analyzing workplace health issues with different variables in a research model applied to different types of health organizations. Our findings support the importance of the health and safety conditions of the workplace as essential for the wellbeing of the employees.

Our findings have some practical implications as compared to the present literature. The findings suggest that healthcare managers should be more knowledgeable about workplace health issues as well as job stress, interpersonal conflict and turnover intention of the employees. As job stress is correlated with the productivity of the employees, it is vital for organizations to monitor and reduce the levels of job stress and interpersonal conflicts resulting in higher turnover intentions with application of the required strategic HR policies. Managers should apply the required policies to control occupational stressors and interpersonal conflict variables. Basically managers need to increase the job satisfaction levels of the employees with fair policies, healthy and safe work conditions, equal compensation and equal promotion opportunities.

This study has several limitations. First, the findings were based on a cross-sectional research design so as to explore causal relationships between different demographic variables, job stress, interpersonal conflict and turnover intention. Longitudinal research is needed to have sound and more reliable results. Second, the questionnaire measured only self-reported data. Mixed qualitative and quantitative approaches may be used to ensure a more in-depth understanding of the research model. Third, the research sample was limited to a geographical region and in the future the research sample should be expanded to include a more explorative vision. Therefore, the findings of the study should be interpreted with some caution as the participants represented a limited view of re- ality. Management within the healthcare sector of Turkey must accept the fact that workers who do not feel healthy and safe in their work environments are prone to develop high stress, turnover intention, and conflict with other colleagues. Workers are not keen on leaving the organization; however, they want to be cared about and valued through proper implementation of effective policy measures to reduce injuries and death in the working environment. Therefore, managers should do everything they can to protect employees' health and safety in the organization.

\section{References}

Alexander, J. A., Bloom, J. R., \& Nuchols, B. A. (1994). Nursing turnover and hospital efficiency: an organization-level analysis. Industrial Relations, 33, 505-520. https://doi.org/10.1111/j.1468-232X.1994.tb00355.x

Alli, B. O. (2008). Fundamental principles of occupational health and safety. International Labor Office.

Amponsah-Tawiah, K., \& Mensah, J. (2016). The impact of safety climate on safety related driving behaviors. Transportation Research Part F: Traffic Psychology and Behaviour, 40, 48-55. https://doi.org/10.1016/j. trf.2016.04.002

Annagür, B. (2010). Violence towards health care staff: Risk factors, aftereffects, evaluation and prevention. Current Approaches in Psychiatry, 2, 161-173.

Arshadi, N., \& Damiri, H. (2013). The relationship of job stress with turnover intention and job performance: Moderating role of OBSE. Procedia - Social and Behavioral Sciences, 84, 706-710. https://doi. org/10.1016/j.sbspro.2013.06.631

Baltaş, Z., Atakuman, Y., \& Duman, Y. (1998). Standardization of the perceived stress scale: Perceived stress in middle managers. Paper presented at the 19th International Conference of Stress and Anxiety Research Society, Istanbul.

Barrows, C. (1990). Employee turnover: Implications for hotel managers. Hospitality Review, 8, 24-31.

Basińska, M. A., \& Sołtys, M. (2020). Personal resources and flexibility in coping with stress depending on perceived stress in a group of cancer patients. Health Psychology Report, 8, 107-119. https://doi. org/10.5114/hpr.2020.93781

Bayraktaroğlu, S., Aras, M., \& Atay, E. (2018). The perception of employees on occupational safety and accident: a research on blue-collar workers. International Journal of Management and Social Researches, 15, 1-15.

Bennett, R. J., \& Robinson, S. L. (2000). Development of a measure of workplace deviance. Journal of Applied Psychology, 85, 349-360. https://doi. org/10.1037/0021-9010.85.3.349

Bhagawati, B. (2015). Basics of occupational safety and health. IOSR Journal of Environmental Science, Toxicology and Food Technology, 1, 91-94. 
Blau, P. M. (1964). Exchange and power in social life. Wiley.

Budd, J. W., Arvey, R. D., \& Lawless, P. (1996). Correlates and consequences of workplace violence. Journal of Occupational Health Psychology, 1, 197210. https://doi.org/10.1037/1076-8998.1.2.197

Cetinkaya, G., \& Aras, D. (2017). Work stress, perception of job safety, and job satisfaction of rope access technicians and the relationship among them. Mediterranean Journal of Humanities, 7, 125-132. https://doi.org/10.13114/MJH.2017.352

Chen, M. F., Lin, C. P., \& Lien, G. Y. (2011). Modelling job stress as a mediating role in predicting turnover intention. The Service Industries Journal, 31, 13271345. https://doi.org/10.1080/02642060903437543.

Civil Aviation Safety Authority (2002). Safety management systems: Getting started. Civil Aviation Safety Authority.

Cohen, S., \& Williamson, G. (1988). Perceived stress in a probability sample of the United States. In S. Spacapan \& S. Oskamp (Eds.), The social psychology of health: Claremont symposium on applied social psychology (pp. 31-67). Sage.

Coşkun, S., \& Karahan, S. (2019). Acil servis çalışanlarında şiddete maruz kalma durumunun incelenmesi [An analysis of exposure to violence in emergency service workers]. ACU Sağlık Bil Derg, 10, 493-499. https://doi.org/10.31067/0.2018.90

Edwards, J. R., \& Rothbard, N. P. (1999). Work and family stress and well-being: an examination of person-environment fit in the work and family domains. Organizational Behavior and Human Decision Processes, 77, 85-129. https://doi.org/10.1006/ obhd.1998.2813

Ergör, O. A., Demiral, Y., \& Piyal, Y. B. (2003). A significant outcome of work life: occupational accidents in a developing country, Turkey. Journal of Occupational Health, 45, 74-80. https://doi.org/10.1539/ joh.45.74

Firth, L., Mellor, D. J., Moore, K. A., \& Loquet, C. (2004). How can managers reduce employee intention to quit? Journal of Managerial Psychology, 19, 170-187. https://doi.org/10.1108/02683940410526127

Frone, M. R. (2000). Work-family conflict and employee psychiatric disorders: The national comorbidity survey. Journal of Applied Psychology, 85, 888-895. https://doi.org/10.1037/0021-9010.85.6.888

Geldart, S., Smith, C. A., Shannon, H. S., \& Lohfeld, L. (2010). Organizational practices and workplace health and safety: a cross-sectional study in manufacturing companies. Safety Science, 48, 562-569. https://doi.org/10.1016/j.ssci.2010.01.004

Griffeth, R. W., Hom, P. W., \& Gaertner, S. (2000). A meta-analysis of antecedents and correlates of employee turnover: Update, moderator tests, and research implications for the next millennium. Journal of Management, 26, 463-488. https://doi. org/10.1177/014920630002600305
Guimaraes, T. (1997). Assessing employee turnover intentions before/after TQM. International Journal of Quality \& Reliability Management, 14, 46-63. https://doi.org/10.1108/02656719710156770

Gustafson, C. M. (2002). Employee turnover: a study of private clubs in the USA. International Journal of Contemporary Hospitality Management, 14, 106113. https://doi.org/10.1108/09596110210424385

Gyekye, S. A. (2005). Workers' perceptions of workplace safety and job satisfaction. International Journal of Occupational Safety and Ergonomics, 11, 291302. https://doi.org/10.1080/10803548.2005.11076650

Hart, R., McDonald, J., \& Rock, S. (2004). The mindbody connection: Workplace interpersonal conflict, stress \& the risk of injury. Retrieved from https:// www.ehstoday.com/archive/article/21909463/themindbody-connection-workplace-conflict-stressthe-risk-of-injury

Haq, I. U. (2011). The impact of interpersonal conflict on job outcomes: Mediating role of perception of organizational politics. Social and Behavioral Sciences, 25, 287-310. https://doi.org/10.1016/j.sbspro.2011.10.549

Hauge, L. J., Skogstad, A., \& Einarsen, S. (2007). Relationships between stressful work environments and bullying: Results of a large representative study. Work \& Stress, 21, 220-242. https://doi. org/10.1080/02678370701705810

Hızıroğlu, A., Taşçı, T., \& Özçelik, T. Ö. (2012). Analysis of current occupational health and safety situation and needs of SMEs in Turkey. Journal of Labor Relations, 3, 66-88.

Hwang, J., Lee, J. J., Park, S., Chang, H., \& Kim, S. S. (2014). The impact of occupational stress on employee's turnover intention in the luxury hotel segment. International Journal of Hospitality \& Tourism, 15, 60-77. https://doi.org/10.1080/15256480.2014.872898

International Labor Organization (2019). Safety and health at the heart of the future of work: Building on 100 years of experience. Retrieved from: https://www.ilo.org/safework/events/safeday/ WCMS_686645/lang--en/index.htm

Johnson, J. T., Griffeth, R. W., \& Griffin, M. (2000). Factors discriminating functional and dysfunctional salesforce turnover. Journal of Business \& Industrial Marketing, 15, 399-415. https://doi.org/10. 1108/08858620010349493

Khan, E. A., Aqeel, M., \& Riaz, M. A. (2014). Impact of job stress on job attitudes and life satisfaction in college lecturers. International Journal of Information \& Education Technology, 4, 270-273. https:// doi.org/10.7763/IJIET.2014.V4.411

Konstantopoulos, N., Sakas, D. P., \& Triantafyllopoulos, Y. (2009). The strategy of stakeholder briefing during merger negotiation in the bank market. Journal of Management Development, 28, 622-632. https://doi.org/10.1108/02621710910972724

Labov, B. (1997). Inspiring employees the easy way. Incentive, 171, 114-118.
Health and safety, job stress, interpersonal conflict, and turnover intention 
Yılmaz Palanci,

Cengiz Mengenci, Serkan

Bayraktaroğlu, Abdurrahim Emhan
Leblebici, D. (2012). Impact of workplace quality on employee productivity: Case study of a bank in Turkey. Journal of Business Economics and Finance, 1, 38-49.

Liu, S., Gyabeng, E., Sewu, G. J. A., Nkrumah, N. K., \& Dartey, B. (2019). Occupational health and safety and turnover intention in the Ghanaian power industry: The mediating effect of organizational commitment. BioMed Research International, article 3273045. https://doi.org/10.1155/2019/3273045

Lu, F. J. H., Hsu, Y. W., Chan, Y. S., Cheen, J. R., \& Kao, K. T. (2012). Assessing college student-athletes' life stress: initial measurement development and validation. Measurement in Physical Education and Exercise Science, 16, 254-267. https://doi.org/ 10.1080/1091367X.2012.693371

Macdonald, C., Chamberlain, K., Long, N., \& Mirfin, K. (2000). Stress and mental health status associated with peacekeeping duty for New Zealand defense force personnel. Stress Medicine, 15, 235-241. https://doi.org/10.1002/(SICI)1099-1700(199910) 15:4<235::AID-SMI819>3.0.CO;2-U

Magner, N., Welker, R., \& Johnson, G. (1996). The interactive effects of participation and outcome favorability in performance appraisal on turnover intentions and evaluations of supervisors. Journal of Occupational and Organizational Psychology, 69, 135-143. https:// doi.org/10.1111/j.2044-8325.1996.tb00605.x

Mano-Negrin, R., \& Tzafrir, S. S. (2004). Job search modes and turnover. Career Development International, 9, 442-458. https://doi.org/10.1108/13620430410550727

Meydanlioğlu, A. (2013). Sağlık çalışanlarının sağlığı ve güvenliği [Health and safety of health care workers]. Balıkesir Sağlık Bilimleri Dergisi, 2, 192-199.

Michael, J. H., Evans, D. D., Jansen, K. J., \& Haight, J. M. (2005). Management commitment to safety as organizational support: Relationships with non-safety outcomes in wood manufacturing employees. Journal of Safety Research, 36, 171-179. https://doi. org/10.1016/j.jsr.2005.03.002

Mulki, J. P., Jaramillo, F., Goad, E. A., \& Pesquera, M. R., (2015). Regulation of emotions, interpersonal conflict, and job performance for salespeople. Journal of Business Research, 68, 623-630. https://doi. org/10.1016/j.jbusres.2014.08.009

Neal, A., \& Griffin, M. (2004). Safety climate and safety at work. In J. Barling \& M. R. Frone (Eds.), The psychology of workplace safety (pp. 15-34). APA Publishing.

Notelaers, G., Van der Heijden, B., Guenter, H., Nielsen, M. B., \& Einarsen, S. V. (2018). Do interpersonal conflict, aggression and bullying at the workplace overlap? A latent class modeling approach. Frontiers in Psychology, 9, 1743. https:// doi.org/10.3389/fpsyg.2018.01743

Ornek, O. K., \& Esin, M. N. (2015). Occupational health nursing in Turkey: an international update. Workplace Health and Safety, 63, 33-38. https:// doi.org/10.1177/2165079914565349
Özay, M. E., \& Coskun, S. (2017). Analysis of occupational health and safety data between 2003-2015 in Turkey. Journal of Business, Economics and Finance, 6, 375-385. https://doi.org/10.17261/Pressacademia.2017.770

Özkan, Ö., \& Emiroğlu, N. (2006). Hastane sağlık çalışanlarına yönelik işçi sağlığı ve iş güvenliği hizmetleri [Occupational health and safety services towards hospital health employees]. Cumhuriyet Üniversitesi Hemşirelik Yüksek Okulu Dergisi, 10, 43-50.

Öztürk, H., Babacan, E., \& Anahar, E. (2012). Hastanede çalışan sağlık personelinin iş güvenliği [Occupational safety of healthcare personnel working in hospital]. Gümüşhane Üniversitesi Sağlık Bilimleri Dergisi, 1, 252-268.

Porter, L. W., \& Steers, R. M. (1973). Organizational, work, and personal factors in employee turnover and absenteeism. Psychological Bulletin, 80, 151176. https://doi.org/10.1037/h0034829.

Price, J. L. (1977). The study of turnover. lowa State University Press.

Shaukat, R., Yousaf, A., \& Sanders, K. (2017). Examining the linkages between relationship conflict, performance and turnover intentions: Role of job burnout as a mediator. International Journal of Conflict Management, 28, 4-23. https://doi.org/10.1108/ IJCMA-08-2015-0051

Simon, A. F., Salazar, E., Chou, M., \& Krantz, D. E. (2007). A new behavior paradigm to study social behavior. Paper presented at 48th Annual Drosophila Research Conference, Philadelphia, PA.

Stovel, M., \& Bontis, N. (2002). Voluntary turnover: Knowledge management - friend or foe? Journal of Intellectual Capital, 3, 303-322. https://doi. org/10.1108/14691930210435633

Ulubeyli, S., Kazaz, A., \& Er, B. (2014). Health and safety perception of workers in Turkey: a survey of construction sites. International Journal of Occupational Safety and Ergonomics, 20, 323-338. https://doi.org/10.1080/10803548.2014.11077043

Vredenburgh, A. G. (2001). Organizational safety: Which management practices are most effective in reducing employee injury rates? Journal of Safety Research, 33, 259-276. https://doi.org/10.1016/ S0022-4375(02)00016-6

Walsh, J. P., Ashford, S. J., \& Hill, T. E. (1985). Feedback obstruction: The influence of the information environment on employee turnover intentions. Human Relations, 38, 23-46. https://doi.org/ 10.1177/001872678503800102

Yavuz, M., \& Akca, M. (2018). Conflict, work stress, job burnout, and turnover intention: Examining differences based on marital status and gender. Journal of Business Research - Turk, 10, 827-846. https://doi.org/10.20491/isarder.2018.457

Zuber, A. (2001). A career in food service cons: High turnover. Nation's Restaurant News, 35, 147-148. 